\title{
The Understanding of Islamic Moderation (wasațiyyah al-Islam) and the Hadiths on Inter-religious relations in the Javanese Pesantrens
}

\author{
Muhammad Irfan Helmy \\ Institut Agama Islam Negeri Salatiga \\ E-mail:mihelmy@iainsalatiga.ac.id
}

Achmad Darojat Jumadil Kubro

Institut Agama Islam Negeri Salatiga

E-mail: darojat.jumadil@gmail.com

Muhamad Ali

University of California Riverside

E-mail:muhamad.ali@ucr.edu

DOI:10.18326/ijims.v11i2.377-401

\begin{abstract}
The Wasatiyyah of Islam has been described as the value of moderation in Islam, emphasizing justice, balance, and tolerance. The Quran and al-Hadith contain these values, but they are often misunderstood and misapplied. The pesantren or Islamic boarding school, is an educational institution close to the community and it plays a key role in instilling the moderate values of Islam. This article aims at discussing the moderation of Islam in relation to other religions and religious
\end{abstract}


communities as taught through the hadith and as understood among the teachers and students of three pesantrens in central Java. It investigates the teachers and students' views of Islam as a religion among other religions, and their attitudes as the pesantren community toward other religious believers. It combines textual research employing a mukhtalif al-hadi approach and living or lived hadith research. It argues that the hadiths on inter-religious relationship are understood as a necessity to be just towards faith, which means that one should believe that their faith is correct but should remain tolerant towards other faiths. This means giving others the right to choose and implement their own faiths, behaving in a balanced way, and conducting healthy competition in various fields, especially the proselytization or dawah. With this textual understanding, the students have generally been quite well informed about the values of Islamic moderation and they seek to apply it in their religious and social life. The students have learned about the hadiths on interreligious relations and the moderate values primarily from their teachers although they have read directly from books and sometimes from social media.

Wasatiyyah Islam digambarkan sebagai nilai moderasi dalam Islam, menekankan keadilan, keseimbangan, dan toleransi. Al-Qur'an dan al-Hadis mengandung nilai-nilai ini, tetapi sering disalahpahami dan diterapkan secara salah. Pesantren merupakan lembaga pendidikan yang dekat dengan masyarakat dan berperan penting dalam menanamkan nilai-nilai moderat Islam. Artikel ini bertujuan membahas moderasi Islam dalam kaitannya dengan agama dan umat beragama lain sebagaimana diajarkan melalui hadis dan sebagaimana dipahami para guru dan santri di tiga pesantren di Jawa Tengah. Artikel ini menyelidiki pandangan siswa tentang Islam sebagai agama di antara agama-agama lain, dan sikap mereka sebagai komunitas pesantren terhadap pemeluk agama lain. Ini menggabungkan penelitian tekstual yang menggunakan pendekatan mukhtalif al-hadis dan penelitian hadits hidup (living or lived hadith). Artikel ini berargumen bahwa hadis-hadis tentang hubungan antarumat beragama dipahami sebagai keharusan untuk bersikap adil terhadap keimanan, yang berarti bahwa seseorang harus percaya bahwa imannya sendiri benar tetapi harus tetap toleran terhadap agama lain. Ini artinya memberikan hak kepada orang lain untuk memilih dan menjalankan keyakinannya sendiri, berperilaku seimbang, dan melakukan persaingan yang sehat di berbagai bidang, terutama dakwah. Dengan pemahaman 
tekstual ini, para santri secara umum telah terinformasi dengan baik tentang nilai-nilai moderasi Islam dan mereka terus menerapkannya dalam kehidupan keagamaan dan sosial mereka. Para siswa telah belajar tentang hadits tentang hubungan antaragama dan nilai-nilai moderat terutama dari guru mereka meskipun mereka telah membaca langsung dari buku dan kadang-kadang dari media sosial.

Keywords: Wasatiyyah Islam; Inter-religious relationship; Tolerance; Living hadith

\section{Introduction}

Wasatiyyah is one of the so many Islamic teachings. This terminology is even preserved by Allah in the Quran Surah al-Baqarah verse 143, "And so We have made you ummatan wasatan..." This verse is addressed to Muslims in the center (balanced) line, without an extreme Islamic understanding and practice. When Islam is deemed a radical and terrorist religion by Western countries, the appellation ummatan wasatan finds its momentum to be a middle way to deaccelerate Muslims' too strict and extreme actions, which clearly contradict Islamic teaching. ${ }^{1}$

The closest equivalent to the term wasatiyyah is moderation. Moderation is the choice to have a perspective, attitude, and behavior in the middle of the existing extreme choices. Easiness, being in the middle, and moderation are the characteristics of Islamic law, and even the most important characteristics of Islamic law. ${ }^{2}$ By analogy, a moderate characteristic is like a motion from the edge that always tends to the center or the axis (centripetal), while extremism is a reverse motion away from the center or the axis, towards the outer and extreme side (centrifugal). ${ }^{3}$

${ }^{1}$ M. Zainuddin and Muhammad In'an Esha, Islam Moderat: Konsepsi, Interpretasi, dan Aksi Malang: UIN Maliki Press, 2016, 75.

2Ahmad Thayyib, Jihad Melawan Teror, Jakarta: Pusat Studi Al-Qur'an, 2016, 202.

${ }^{3}$ Research and Development and Training Agency of the Ministry of Religious Affairs of the Republic of Indonesia, Moderasi Beragama, Jakarta: Ministry of Religious Affairs of the Republic of Indonesia, 2019, 17. 
With regards to the inter-religious relationship, wasatiyyah is key to the creation of tolerance and harmony at local, national, and global levels. By behaving moderately, religious people will ideally treat others with respect, accept differences, and live together in peace and harmony. It is quite compatible for Indonesia with its multicultural society to apply religious moderation, which it is not only a choice, but a necessity.

Muslims, however, sometimes misunderstand Islamic teachings that occasionally make them away from tawassut. Such misunderstanding may sometimes start from a false understanding of the main sources of Islamic law, the Quran, and al-Hadith. The Quranic teaching that is often misunderstood is the verses on qital and jihad. ${ }^{4}$ Meanwhile, in hadith it is inequality in understanding hadiths of which contents seem different or even contradictory, especially hadiths on the relation between Muslims and other religious believers. Performing one hadith sometimes requires undoing another hadith. Such choice may even lead to a conclusion with quite a big impact. In fact, there are indeed hadiths that suggest harmony, but there are also hadiths that suggest keeping away from and even fighting other religious believers.

There are three intolerant hadiths. First, hadith on the command to fight humans until they take the shahada:

I have been ordered (by Allah) to fight against the people until they testify that none has the right to be worshipped but Allah and that Muhammad is Allah's Apostle, and offer the prayers perfectly and give the obligatory charity, so if they perform that, then they save their lives and property from me except for Islamic laws and then their reckoning (accounts) will be done by Allah. ${ }^{5}$

\footnotetext{
${ }^{4}$ Arif Chasbullah, "Deradikalisasi terhadap Penafsiran Ayat-Ayat Qitāl," Fikri, Volume 2, Number 2 (2017), 407-424.

${ }^{5}$ Muhammad bin Isma'il Bukhari, Al-Jāmi' al-Saḥih, Beirut: Dar Ibn Katsir, 1987, 11, hadith number 25 .
} 
Second, the hadith that states all Jews and Christians will go to hell:

By Him in Whose hand is the life of Muhammad, he who amongst the community of Jews or Christians hears about me, but does not affirm his belief in that with which I have been sent and dies in this state (of disbelief), he shall be but one of the denizens of Hell-Fire. ${ }^{6}$

Third, the hadith on Jews and the Christians when meeting them on the roads and the prohibition from greeting them first, "Do not greet the Jews and the Christians before they greet you and when you meet any one of them on the roads force him to go to the narrowest part of it."

Contradictorily, there are three tolerant hadiths. First, the hadith on the prohibition from replying a bad prayer with a bad prayer:

A group of Jews entered upon the Prophet and said, "As-SamuAlaikum." (i.e. death be upon you). I understood it and said, "Wa-Alaikum As-Samu wal-la'n. (death and the curse of Allah be Upon you)." Allah's Apostle said "Be calm, O 'Aisha! Allah loves that on, should be kind and lenient in all matters." I said, “O Allah's Apostle! Haven't you heard what they (the Jews) have said?" Allah's Apostle said "I have (already) said (to them) "And upon you!

Second, the hadith on the necessity to respect a Jew's body:

A funeral procession passed in front of us and the Prophet stood up and we too stood up. We said, 'O Allah's Apostle! This is the funeral procession of a Jew." He said, "Whenever you see a funeral procession, you should stand up. ${ }^{9}$

And third, the hadith in which the Prophet allows a priest to pray in the mosque of the prophet:

${ }^{6}$ Muslim bin Hajjaj, Sahịh Muslim, Beirut: Dar Ihya al-Turots al-'Arobiy, n.d., 105, hadith number 155 .

${ }^{7}$ Muslim bin Hajjaj, Șahị Muslim, 1514, hadith number 2169.

${ }^{8}$ Bukhari, Al-Jāmi' Al-Sahih, 1850, hadith number 6024.

${ }^{9}$ Bukhari, Al-Jāmi' Al-Sahịh, 367, hadith number 1311. 
When a Najran group visited the Prophet, they entered his mosque after 'asr prayer. Then the time for their prayer came, and they prayed in his mosque. The people tried to stop them but the Prophet said "Let them be!" Then they faced east and did prayer. ${ }^{10}$

In the reality of Islamic diversity, pesantren is the miniature of Islam in Indonesia. ${ }^{11}$ Pesantren, as a place for in-depth study of Islam ${ }^{12}$ and the basis of Islamic religious education closest to the society, is the spearhead in instilling tawassut attitude. How they build tolerance understanding and practice may be something that is not noted by any more professional educational institutions. On this basis, it is important to conduct research on this matter.

Based on the issues above, this article reviews four subject matters. First is the insight of hadith of Prophet Saw on inter-religious relationship. Second is pesantren society's view of Islam as a religion among other religions. Third is pesantren society's tolerance to other religious believers. Fourth is how pesantren society understands and practices the wasatiyyah attitude in their religious life.

In the document composed by the Committee of Quran Validation (Lajnah Pentashih Mushaf al-Qura'n) of the Ministry of Religious Affairs of the Republic of Indonesia, it is explained that the Islamic moderation principles are justice ('adālah), balance (tawāzun), and tolerance (tasāmuh). The term al-adl is interpreted by some mufassir (interpreters of the Quran), such as by at Tabari as a teaching where Allah orders Prophet Muhammad to enforce and spread it in the form of al-insaf. In other documentation,

${ }^{10}$ Ahmad bin al-Husain Baihaqi, Dalā'il al-Nubuwwah, 1st ed., vol. 5, Beirut: Dar al-Kutub al-Ilmiyah, 1408H, 382.

${ }^{11}$ Syamsun Ni'am, "Pesantren: The Miniature of Moderate Islam in Indonesia”, Indonesian Journal of Islam and Muslim Societies, Volume 5, Number 1 (2015), 111-134.

${ }^{12}$ Ahmad Baidowi et al., "Theology of Health of Quranic Pesantren in the Time of COVID-19,” HTS Teologiese Studies/Theological Studies, Volume 77, Number 4 (2021), 1-11. 
the term al'adl also means a testimony that there is no God but Allah. In Tafsir Ibn Kathir, the term al-'adl bears the meaning of worshipping Allah justly, that is justly and moderately (al-qist wa al-muwazanah). Tafseer of Jalalain defines al'adl as al-Tauhid and al-insaf. In Tafseer of Al-Mawardi, meanwhile, the meaning of Al'adl is divided into three, namely al-Tauhid, bearing witness that there is no God but Allah, doing something correctly, and behaving equally in do good deeds for Allah, both spiritual and physical deeds. ${ }^{13}$

Abdul Mustaqim states that behaving in a just and balanced way should not only be carried out in terms of tenet and worship, but also in any deeds and actions. ${ }^{14}$ Keeping these two balanced is one of the basic principles of religious moderation. For example, balance between mind and revelation, between physique and spirituality, between right and obligation, between individual interest and communal interest, between something necessary and voluntary, between religious text and religious figures' ijtihad, between an ideal idea and reality, and between past and future. The core of religious moderation is justice and balance in viewing, behaving, and practicing all of the paired concepts.

Mohammad Hashim Kamali describes that the principle of balance and justice in the concept of moderation (wasatiyyah) bears the meaning that, with regard to religion, an individual should not have any extreme view, but should always seek a point of agreement. ${ }^{15}$ The wasatiyah principle is an important aspect in Islam, which is often forgotten by its believers, while wasatiyah is the essence of Islamic teaching. Tasamuh is described by the Quran in Surah al-Kafirun verse 1-6. Prophet Muhammad is asked by

${ }^{13}$ Lajnah Pentashihan Mushaf Al-Qur'an, Moderasi Islam (Tafsir Al-Qur'an Tematik), Jakarta: Ministry of Religious Affairs of the Republic of Indonesia, 2012, 20.

${ }^{14}$ Abdul Mustaqim, Tafsir Maqosidi, Indonesia: Daar al-Fikr, 2020, 3.

${ }^{15}$ Mohammad Hashim Kamali, The Middle Path of Moderation in Islam: The Quranic Principle of Wasatiyyah, New York: Oxford University Press, 2015), 14. 
Allah not to follow other religious believer's invitation, but also not to force others to follow him. In the fourth verse, Allah orders Prophet Muhammad to prioritize equality in order to realize inter-religious tolerance.

Mohamad Nuryansah in his article on hadith on the order to "Fight Humans until They Declare That There Is No God but Allah" studies the withdrawal of maghza and maskut 'anhu from the hadith. In his opinion, jihad in Islam should be carried out politely. ${ }^{16}$ Salamah Noorhidayati discusses contradictory hadiths with a socio-historical reconstruction approach. In her opinion, those hadiths must be entirely derived from their universal principles so that they will not contradict each other and all of them teach about peace. ${ }^{17}$ Ahmad Husni Haji Hasan in 'An Islamic Perspective of the Interfaith Dialogue amidst Current Inter-religious Tensions Worldwide,' confirms that the construction of messages in the Quran and Hadith in inter-religious relationship actually gives room for dialog. ${ }^{18}$ Mohd Roslan and two other Malaysian researchers in 'Analyzing the Conceptual Framework of Religious Freedom And Interreligious Relationship in Islam' conclude that Islam encourages a harmonious relationship between people of different religions, cultures, and civilizations in order to realize peace and development of all aspects of humanity harmoniously. ${ }^{19}$

Research on the role of pesantren in carrying out inter-religious harmony has been conducted, among others, by Nurul Hakim, who concludes that

\footnotetext{
${ }^{16}$ Mohamad Nuryansah, "Aplikasi Hermeneutika Nashr Hamid Abu Zaid terhadap Hadits Nabi”, Journal of Islamic Studies and Humanities, Volume 1, Number 2 (2016), 259-276.

${ }^{17}$ Salamah Noorhidayati, "Relasi Antar Umat Beragama dalam Perpektif Hadits," KALAM, Volume 10, Number 2 (2016), 501-514.

${ }^{18} \mathrm{Ahmad}$ Husni Hassan, "An Islamic Perspective of the Interfaith Dialogue amidst Current Inter-Religious Tensions Worldwide," Global Journal Al-Thaqafah, Volume 1, Number 1 (2011), 25-34.

${ }^{19}$ Mohd Roslan Mohd Nor, Issa Khan, and Mohammad Elius, "Analysing the Conceptual Framework of Religious Freedom and Interreligious Relationship in Islam," Indonesian Journal of Islam and Muslim Societies, Volume 8, Number 2 (2018), 309-330.
} 
pesantren's effort to realize harmony is to have santri habituated to joining in social activities that involve all people of different religions. Kyai's exemplary role and learning program also contribute to influencing the effort to build harmony. ${ }^{20}$

Umi Sumbulah in research on understanding three big Islamic mass organizations in Indonesia with regard to the position of ahl al-kitāb and how to behave towards them shows that there is difference in the evaluation of who should be called ahl al-kitāb. Top figures of NU and Muhammadiyah state that they include all Christians and Jews, whether they acknowledge Allah's oneness or not. Meanwhile, top figures of Hizbut Tahrir state that ahl al-kitāab can only be addressed to Christians and Jews who still maintain the purity of teaching of Allah's oneness. However, they agree that doing good deeds for all Christians and Jews is what Muslims must do. ${ }^{21}$ Research on moderate Islam was conducted by Haji Masri and friends in the inland areas of West Kalimantan to reveal local wisdoms that can form harmony with Islam. First, culture presents food. Second, a friendly attitude may serve as the key to success. Third, lineage is a blessing that needs to be respected. Fourth, hospitality can invite happiness. Fifth is work ethic, and sixth are noble manners. ${ }^{22}$

Differently from the research studies above, this research focuses on the discourse of wasatiyyah Islam and its various indicators in the framework of inter-religious relationship and harmony and their implementation in pesantren society. This research first studied contradictory hadiths on

\footnotetext{
${ }^{20}$ Nurul Hakim, Peran Pondok Pesantren dalam Membina Toleransi Kerukunan Antar Umat Beragama: Studi Kasus Pondok Pesantren Salafiyah Az-Zuhri Kota Semarang", Final Project, Semarang, UIN Walisongo, 2015.

${ }^{21}$ Umi Sumbulah, "Islam dan Ahl Al-Kitab," Al-Tahrir: Journal of Islamic Thinking, Volume 11, Number 1 (2011), 151-171.

${ }^{22}$ Zaenuddin Hudi Prasojo, Elmansyah Elmansyah, and Muhammed Sahrin Haji Masri, "Moderate Islam and the Social Construction of Multi-Ethnic Communities", Indonesian Journal of Islam and Muslim Societies, Volume 9, Number 2 (2019), 217-237.
} 
inter-religious relationships and observed the extent to which wasatiyyah Islam was understood and implemented by pesantren society. This research also studied the extent of pesantren society's understanding of hadiths on inter-religious relationship as the factor that encourages their actions and mass media's role in forming their understanding and actions.

This research combined two types of research, namely library research on hadith and research on living hadith. The two were conducted simultaneously since they can strengthen and cover the weaknesses of each other, ${ }^{23}$ as what was conducted by Barbara D. Metcalf, which she conducted on Living Sunnah from hadith texts that were compiled, printed and spread in society. ${ }^{24}$

In the library research on hadiths, each hadith obtained along with its explanation were analyzed from the perspective of mukhtalif al-hadith science. Mukhtalif al-hadith science has three main principles in settling hadith contradiction. First, it is to compromise two hadiths as long as it is possible by implementing the two in different times as per condition. Second, when it is impossible to compromise, because of the two's frontal contradiction, the calendar (tarjih) of one of the hadiths is known to have more strengthening elements. ${ }^{25}$

The research on living hadith used a phenomenological approach. The research subjects were santri (a person who seeks Islamic knowledge) in three different pesantren. Student pesantren was represented by Pondok Pesantren al-Ihsan al-Amin in Kecandran Sub-district, Salatiga City. All santri in this pesantren were also college students. The total respondents

\footnotetext{
${ }^{23}$ Muhamad Ali, “Kajian Naskah dan Kajian Living Qur’ān dan Living Hadith”, Journal of Qur'an and Hadith Studies, Volume 4, Number 2 (2015), 147-167.

${ }^{24}$ Barbara D. Metcalf, "Living Hadith in the Tablighi Jamāa-at," The Journal of Asian Studies, Volume 52, Number 3 (1993), 584-608.

${ }^{25}$ Muhammad bin Idris Syafi' i, Ikhtilaf al-Hadis, II, Beirut: Dar al-Kutub al-Ilmiyah, 1429 H, 39 .
} 
were 47 (forty seven) santri. They were 18-24 years old. Their duration of taking education in the pondok pesantren varied greatly. Eight santri were there for less than a year. Six santri had been there for a year. Thirteen santri had been there for two years. Fifteen santri had been there for three years. Four santri had been there for four years and a santri had been there for five years.

Classical pesantren was represented by Pondok Pesantren Darul Ulum in Reksosari Village, Suruh District, Semarang Regency. The students in this pesantren were dominated by traditional santri. All respondents were santri who had taken education in the pondok pesantren for five years or more. They were totally 35 santri. They were averagely $17-22$ years old. Meanwhile, the mixed pesantren was Pondok Pesantren Hidayatul Mubtadi-ien in Kalibening Sub-district, Salatiga City. In this pesantren, the number of santri who also took general education and who took only religious education was relatively balanced. The total respondents were 28 (twenty-eight) santri. They were between 16-24 years old. They had received education in the pesantren ranging from $2-5$ years.

\section{The hadiths on inter-religious relationship}

There is an important theme of inter-religious relationship of the hadith of the Prophet. On the hadith on the order to fight humans until they take shahada, the explanation can be found in the sabab wurūd of hadith and on the definition of sharfi. The sabab wurūd was stated by Ibrahim bin Muhammad on the Prophet's order to cease war when the enemy had embraced Islam. ${ }^{26}$ Meanwhile, the explanation sharfi of the term uqatil is that it is a reciprocal form of war that is a work done by attackers and those attacked simultaneously. It is not attacking from behind, not oppression,

\footnotetext{
${ }^{26}$ Ibrahim bin Muhammad, Al-Bayān Wa al-Ta'rif Fi Asbāb Wurūd al-Hadith al-Shariff, vol. 1, Beirut: Dar al-Kutub al-Arabiy, n.d., 168.
} 
but also not fleeing from an attack. ${ }^{27}$

Meanwhile, on the hadith that all Jews and Christians will go to hell, the explanation can be found on the sabab wurüd and syarah hadith. The sabab wuru $\bar{d}$ of this hadith is that the Prophet asked Jews and Christians who remained holding their scripture even if they had met the Prophet. ${ }^{28}$ Al-Qadi Iyyad then explained that this hadith also meant that Jews and Christians who had not obtained dawah Islam would not be subject to this law. ${ }^{29}$ It is clear that this hadith purely discusses faith, instead of harmony.

In line with the hadith above, on the hadith on prohibiting Muslims from greeting Jews and Christians when meeting them on the road, the explanation can be found on the syarah hadith. The prohibition from greeting is that there is no necessity. ${ }^{30}$ Meanwhile, the order to force Jews and Christians to the edge of road is not an order to hurt them at all, but a prohibition from showing a Muslim's weakness when they have to compete on the road and even glorifying them by giving up. ${ }^{31}$

The explanation above is confirmed by a hadith on the prohibition from replying a bad prayer with a bad prayer, and the explanation can be found on the syarah hadith. Al-Qadli Iyyad explains that this hadith shows Muslims' necessity to practice noble character at all times. They should not be provoked by others' wickedness to respond to it with wickedness, but with kindness. ${ }^{32}$

On the other hand, on the hadith on the order to respect a Jew's body, the explanation can be found in the syarah hadith. Ibnu Battal explains that

\footnotetext{
${ }^{27}$ Mustofa bin Muhammad Salim Gulayini, Jāmi' al-Durūs al-'Arabiyyah, XXVIII, Beirut: Maktabah al-Asriyah, 1414H, 219.

${ }^{28}$ 'Abdurrahman bin Abi Bakr Suyuti, Al-Luma' Fi Asbāb Wurūd al-Hadith, I, Dar al-Fikr, $1416 \mathrm{H}, 90$.

29'Iyyad Qadi, Ikmāl Al-Mu'allim Bi Fawāid Muslim, I, vol. 1, Mesir: Dar al-Wafa', 1419H, 468.

${ }^{30}$ Musa Syahin Lasyin, Fath al-Mun'im Sharh Saḩị Muslim, I, Dar al-Syuruq, 1423H, 427.

${ }^{31}$ Muhammad Amin bin Ảbdillah, Al-Kaukāb al-Wahhāb Sharh Saḥih Muslim, I, vol. 22, Nejd: Dar al-Minhaj, 1430H, 112.

32'Iyyad Qadi, Ikmāl Al-Mu’allim Bi Fawāid Muslim, I, vol. 7, Mesir: Dar al-Wafa', 1419H, 52.
} 
this hadith explains that anyone that has faced death deserves respect. ${ }^{33}$

\section{Pesantren society's view of Islam as a religion}

In the research on living hadith, the information that will be revealed includes indications of wasatiyyah in the form of justice, tolerance, and balance, and the extent their implementation is based on hadith, and whether there is social media influence in obtaining information on the hadith by santri. With regard to justice, the element observed is whether they can evaluate that their religion remains the most correct regardless of others' right to choose other religion.

All santri in Pondok Pesantren Darul Ulum stated that only Islam was correct. However, they also acknowledged that other religions certainly taught kindness. They considered the concepts of divinity beyond Islam wrong. However, with regard to their belief in the correctness of Islam, all of them acknowledged that they still needed to respect other believers. A santri said briefly, "they are incorrect, but still I need to be nice to them." Other santri said, "they are wrong to have another religion besides Islam. But they cannot be blamed, since they actually start it from their obedience to their scriptures. And their scriptures were also brought by Prophets. "A rather strict statement was made by a santri, "they are dilulu (left astray), given wealth, dignity, power, and science by Allah. But as a Muslim, we still need to respect their belief." A very extreme statement was made by a santri, "Religions other than Islam are infidel, but there is no reason for me to hate them."

In Pondok Pesantren al-Ihsan al-Amin, with regard to questions on the position of religions other than Islam, almost all santri stated 'normal.' Some santri added that the term 'normal' means "for you is your religion,

33'Ali bin Khalaf Ibnu Battal, Syarh Saḥị Al-Bukhari, II, vol. 3, Riyad: Maktabah al-Rusyd, 1423H, 291. 
and for me is my religion." A santri confirmed by adding "Do not interfere in religious affairs." A tone of vigilance was made by a santri, "for their religion is their religion and for me is my religion as long as they do not disturb me worshipping, it is haram for me to be hostile to them." The strictest tone was made by a santri "Religions other than Islam are not pure since their scriptures have been partially renewed." On the opposite side, there was a santri with a liberal response, "all religions are the same. And all religions have their own beliefs." However, when asked about whether they would also enter heaven like Muslim, this santri responded, "no, since only Islam is correct and is acceptable to Allah."

In Pondok Pesantren Hidayatul Mubtadi-ien, for questions on the position of religions other than Islam, all santri responded that only Islam was correct. This started from soft statements that were not about belief, such as "they are religions that teach goodness," followed with relatively stricter forms, such as "they are different from us," until very strict statements, such as "only Islam is correct for sure", or even labeling other non-Muslim adherents as "misguided".

\section{Pesantren society's tolerance of non-Muslims}

In this aspect, research on Living Hadith was conducted to measure the indicators of tolerance. This was conducted by evaluating their willingness to give room for other religious believers to perform their worship. In Pondok Pesantren Darul Ulum, although most of them acknowledged that they did not have any relative, coworker, or even acquaintance of other religions, all santri stated that tolerance is a must. The santri expressed it as follows "respect any of the other believers who are worshipping or gathering." Some of them even straightforwardly mentioned 'tolerance' positively.

In Pondok Pesantren al-Ihsan al-Amin, all santri stated their agreement on tolerance. This included the most basic statement such as "behaving 
normally," "contacting in case of necessity," "not discussing religious matters when meeting them," and "not speaking ill of them." Some seemed to slightly restrict themselves, such as in the statement "just behave reasonably. Appreciate and respect them when they are performing their religious activities. But there were also limitations when we are interacting with them," and another santri said, "behave tolerantly in terms of mu'amalah (social relationship), but with a strong principle and restriction in maintaining my Islamic belief." Some other santri stated more actively, such as in the statement "keep behaving nicely, mutual appreciation and respect" and "keep acting good and tolerantly to each other." A santri made a very positive statement, "...we are like brothers, helping each other."

In response to questions on tolerance, all santri in Pondok Pesantren Hidayatul Mubtadi-ien said yes. Someone said, "we respect them as the form of habl min al-nās." Another responded "we need to be tolerant since this is our obligation in the nation life." Another responded "we should live harmoniously and peacefully." Another responded "always live side by side even with different beliefs." And "I respect them as fellow Indonesians." However, another also showed vigilance by responding "keep tolerant as long as tenet is not mixed up."

\section{Pesantren society's understanding and practice of Wasațiyyah Islam}

In this aspect, research on Living Hadith was conducted to measure the indicators of balance in religious life. This was carried out by evaluating their willingness to interact well in other than worship. When competition is a necessity, they would compete healthily. In preserving a balanced relationship, santri in Pondok Pesantren Darul Ulum acknowledged that this must be realized. Although only a small number of santri had relatives or acquaintances of a different religion, all santri seemed to preserve a 
balanced relationship. This was apparent when they were asked whether they were willing to visit another religious believer who was sick, and they responded with a yes. Even those who did not have any acquaintance of another religion, they were willing, if in the future they would have a friend or neighbor of other religion who was sick, to visit him. But when the question was "will they congratulate or be willing to congratulate other religious believers?" they had different responses. However, when they were asked to choose between hating or respecting other religious believers, they remained with respecting.

With regard to this tawazzun, all santri in Pondok Pesantren al-Ihsan alAmin agreed. They were willing to do humanitarian matters with other religious believers, especially when a relative or friend of other religion was sick, they would visit him. However, with regard to congratulating nonMuslim believers for their religious holiday, they had different responses. Those who were willing to congratulate were on the reason that the congratulation was made to their relative. Meanwhile, they who did not congratulate were on the reason of the prohibition by the Islamic law.

In Pondok Pesantren Hidayatul Mubtadi-ien, all santri responded with agreement in this tawazun dimension. Among them, some responded "we are living side by side without interfering in religious affairs." All santri were willing to respond to their invitation and to visit them when they were sick. Some gave a testimony of good reciprocal relationship by saying, "he spoke quite politely. Thus, I respect him very much." Some said "I respect him since he is quite good in social interaction." Some showed profession relation patterns by saying, "I act professionally in interaction with coworkers of different religion." When the relationship tawazun was related to congratulating other religious believers for their religious holiday, only four santri said it. Three of them said it was because of kinship or friendship, while one said it was because of respect and appreciation. 
Although this one santri did not have any relative of acquaintance of another religion, he was willing to congratulate if one day he met a friend of another religion on his religious holiday. The remainder did not congratulate for prohibition of Islamic law.

Table 1: Tawassut Attitude and Behavior in Pesantren Society

\begin{tabular}{|c|c|c|c|}
\hline $\begin{array}{l}\text { Elements of wasatiyyah } \\
\text { (moderate) Islam }\end{array}$ & $\begin{array}{l}\text { Student } \\
\text { Pesantren }\end{array}$ & $\begin{array}{l}\text { Classical } \\
\text { Pesantren }\end{array}$ & $\begin{array}{c}\text { Combination } \\
\text { Pesantren }\end{array}$ \\
\hline $\begin{array}{l}\text { 'Adālah, testifying } \\
\text { truthfully the oneness of } \\
\text { Allah }\end{array}$ & All santri & All santri & All santri \\
\hline $\begin{array}{l}\text { Tasāmuh, behaving } \\
\text { tolerantly }\end{array}$ & All santri & All santri & All santri \\
\hline $\begin{array}{l}\text { Tawāzun, behaving in a } \\
\text { balanced way, attempting } \\
\text { a point of agreement in } \\
\text { interaction. }\end{array}$ & $\begin{array}{l}\text { In the } \\
\text { very clear } \\
\text { dimension } \\
\text { of humanity, } \\
\text { all santri said } \\
\text { yes. In gray } \\
\text { domain, } \\
\text { however, } \\
\text { such as } \\
\text { congratulation } \\
\text { for religious } \\
\text { holiday, there } \\
\text { is difference. }\end{array}$ & $\begin{array}{l}\text { In the } \\
\text { very clear } \\
\text { dimension } \\
\text { of humanity, } \\
\text { all santri said } \\
\text { yes. In gray } \\
\text { domain, } \\
\text { however, } \\
\text { such as } \\
\text { congratulation } \\
\text { for religious } \\
\text { holiday, there } \\
\text { is difference. }\end{array}$ & $\begin{array}{l}\text { In the } \\
\text { very clear } \\
\text { dimension } \\
\text { of humanity, } \\
\text { all santri said } \\
\text { yes. In gray } \\
\text { domain, } \\
\text { however, } \\
\text { such as } \\
\text { congratulation } \\
\text { for religious } \\
\text { holiday, there } \\
\text { is difference. }\end{array}$ \\
\hline
\end{tabular}

The whole understanding of the santri was obtained from the Quran and ulama (religion scholars). Hadith also directly contributed to santri's understanding in student pesantren. According to the data recorded from Pondok Pesantren Darul Ulum, almost all santri obtained their understanding from the Quran only and from ulama. Only one santri obtained his understanding also from hadith. He read books of hadiths al-Bukhari 
and Muslim on his own. In Pondok Pesantren al-Ihsan al-Amin, more santri obtained their understanding from hadith. There were totally thirty-eight santri. This means that it is almost $80 \%$ out of all respondents. Those hadiths were read from the book Qāmi' al-Tughyān. The remainder obtained their understanding from the Quran only and ulama. In Pondok Pesantren Hidayatul Mubtadi-ien, out of all respondents that gave their response, only one santri obtained his understanding also from the hadith on visiting the sick. The remaining santri obtained their understanding only from the Quran and ulama, especially from ustadz during tenet-character lesson.

Such understanding was mostly transmitted from a teacher to a student. Only five out of forty-seven santri in Pondok Pesantren al-Ihsan al-Amin acknowledged they also obtained information on the relationship with other religious believers from social media. One out of the five santri added that from social media he also found hadith on inter-religious relationships. In Pondok Pesantren Hidayatul Mubtadi-ien only one santri acknowledged to have obtained such understanding from social media, Youtube. In Pondok Pesantren Darul Ulum there was no single santri acknowledging to have obtained such understanding from social media. The reason was that during their stay at pesantren they were not allowed to use any telecommunication device.

The Leader of Pondok Pesantren Ihsan Amin, ustaz Fauzi Ali Hidayat (34 years old), confirmed that there was indeed no special material in their curriculum teaching how Muslims should build a relationship with other non-Muslim believers, either in the form of book of characters or thematic books on hadith. There were books that occasionally contained discussions on correctness of Islam, tolerance, and balance behavior. In such discussions, there were sometimes confirmed propositions, both from the Quran and Hadith. The books included WaSiyyat al-MuStafa, Qāmi' al-Tughyān, and Sulam al-Taufiq. Ustaz only emphasized the explanation and gave examples of application. Sometimes he discussed a topic from a status 
or statements on social media. This was deemed necessary since the santri were free to use telecommunication devices along with their supporting applications. But he did not actively perform dawah in social media. He only deemed it necessary to make preventive measures by monitoring statuses made by his santri.

Ustaz Muhammad Yasin (27 years old), lurah of Pondok Pesantren Hidayatul Mubtadi-ien, and ustaz Muhammad Haidar al-Fahmi (28 years old), senior teacher in Pondok Pesantren Darul Ulum, gave a similar confirmation that there was no special curriculum on tolerance or thematic hadith related to it. Thus, santri's knowledge emerging from hadith was indirect, but from the explanation of books taught. The hadiths delivered in the form of explanation had been internalized and crystalized in the educators' understanding. What was slightly different was those in social media. In Pondok Pesantren Hidayatul Mubtadi-ien and Pondok Pesantren Darul Ulum there was no preventive attempt against infiltration of false concepts circulating in social media since in in Pondok Pesantren Hidayatul Mubtadi-ien there was restriction on the use of telecommunication device and in Pondok Pesantren Darul Ulum there was prohibition from the use of telecommunication devices of any form.

Table 2: Sources that Form Pesantren Society's Understanding of Wasatiyyah Islam

\begin{tabular}{|c|c|c|c|}
\hline $\begin{array}{c}\text { Sources of Understanding } \\
\text { of wasatiyyah (moderate) } \\
\text { Islam }\end{array}$ & $\begin{array}{l}\text { Student } \\
\text { Pesantren }\end{array}$ & $\begin{array}{l}\text { Classical } \\
\text { Pesantren }\end{array}$ & $\begin{array}{l}\text { Combina- } \\
\text { tion Pesant- } \\
\text { ren }\end{array}$ \\
\hline The Quran & All santri & All santri & All santri \\
\hline Al-Hadith & $\begin{array}{l}34 \text { out of } 47 \\
\text { santri }\end{array}$ & $\begin{array}{l}1 \text { out of } 35 \\
\text { santri }\end{array}$ & $\begin{array}{l}1 \text { out of } 28 \\
\text { santri }\end{array}$ \\
\hline Kyai, ulema, ustaz & All santri & All santri & All santri \\
\hline Social media & $\begin{array}{l}5 \text { out of } 47 \\
\text { santri }\end{array}$ & None & $\begin{array}{l}2 \text { out of } 28 \\
\text { santri }\end{array}$ \\
\hline
\end{tabular}


Literature evidences on hadiths on inter-religious relationship show that these hadiths want Muslims to compete healthily with Jews and Christians, not to hurt, let alone oppress them, but not to give up, let alone show their own weaknesses. Their belief is their own responsibility. However, dawah must still be carried out. This is in line with Muhammad Zia-ul-haq's finding in his research on religious diversity. He states that Islamic teaching accepts religious differences as reality in social life. Every individual must show correctness and prioritize kindness. Islam further prohibits religious coercion of any form. ${ }^{34}$ Any forms of terrorism in the name of jihäd (Jihad) are not justifiable. Jihad cannot be defined randomly as war; Jihad is even a means for Muslims to contribute in creating peace on earth. ${ }^{35}$ There is an addition mission for Muslims in this relationship-that if their opponent does bad actions, Muslims should not be provoked to reply with bad action. Finally, anyone who has lived a struggling life deserves respect at the end of his life.

Field research results show that santri in pondok pesantren is represented by two pesantren in Salatiga and one in Semarang Regency; they understand well the values of wasatiyyah Islam and have applied them in their daily life. This is reflected in a belief in the correctness of their religion and noncompromise for any possible correctness of other religion. However, in the same situation, they are tolerant to other religious believers not only by not disturbing, but also by doing good deeds for them. They can even live a balanced life together with other religious believers through cooperation and living side by side in the framework of humanity. Specifically, regarding congratulating other religious believers' religious holiday, however, there is non-uniformity. However, they still realize their respect in other forms. This proves Ronald Lukens-Bull's finding that pesantren society that is

\footnotetext{
${ }^{34}$ Muhammad Zia-ul-haq, "Religious Diversity: An Islamic Perspective", Islamic Studies, Volume 49, Number 4 (2010), 493-519.

${ }^{35}$ Wajidi Sayadi et al., "Theology of Jiḥād Based on the Hadith: Șahịh Bukhāri's Perspective," HTS Teologiese Studies/Theological Studies, Volume 76, Number 4 (2020), 1-8.
} 
educated through Islamic traditional thinking model is not the source of radicalism. On the contrary, they contribute to creating peace life. ${ }^{36}$

The knowledge of hadith on wasatiyyah Islam among santri has not been evenly and massively distributed, but only some santri who happened to learn it on their own or pay more attention to it are capable of absorbing consciously the hadith texts. The rest only absorb it in literal understanding and real action. The understanding transmission process also occurs directly from a teacher to a student. Social media can be deemed as not playing any role in this matter. However, the relatively new idea of wasat iyyah Islam has evidently entered into pesantren society's understanding and practice. This shows that pesantren indeed has an internal system that can accommodate ideas in any period. ${ }^{37}$ At the same time, this also shows that the difference in pesantren's pattern in directing their santri's thinking is that one applies quite strict restrictions and the other enforces them loosely, ${ }^{38}$ which evidently produces something positive.

\section{Conclusion}

In inter-religious relationships, hadiths inform Muslims to behave moderately, to uphold the truth of Islam but with tolerance, and to respect other non-Muslim believers while keeping a balanced relationship without degrading oneself. Since the audience or khithab of hadith is Muslims, those obligated to implement the mandates of hadith are Muslims. Muslims must compete with others without demanding the same from others.

\footnotetext{
${ }^{36}$ Ronald Lukens-Bull, "The Traditions of Pluralism, Accommodation, and Anti-Radicalism in the Pesantren Community," Journal of Indonesian Islam, Volume 2, Number 1 (2008), 1-15.

${ }^{37}$ Hanun Asrohah, "The Dynamics Of Pesantren: Responses toward Modernity and Mechanism in Organizing Transformation," Journal of Indonesian Islam, Volume 5, Number 1 (2011), 66-90.

${ }^{38}$ Hatim Gazali and Abd. Malik, "Pesantren and the Freedom of Thinking: Study of Ma'had Aly Pesantren Sukorejo Situbondo, East Java, Indonesia,” Al-Jami'ah: Journal of Islamic Studies, Volume 47, Number 2 (2009), 295-316.
} 
Tolerance in pesantren society's perspective is something that must be implemented, not only because of peaceful relationships with other humans, but this is also the obligation of faith since Islamic teaching wanted its believers to be tolerant. Thus, the more perfect an individual's faith is, the more tolerant the individual will be.

The method of internalizing the values of wasatiyyah Islam in pesantren is evidently a success. The three pillars of wasatiyyah Islam are firm in pesantren, even without direct presentation of the hadith concept since the hadith values are often delivered by ustaz (religious education teacher) in the form of lesson curriculum. This is, however, not a constraint for internalizing the values of wasatiyyah Islam with hadiths. This can strengthen the basis of wasatiyyah Islam with more precision and can also increase the degree of academic obedience. However, there is also still a possibility that Muslims will also abandon moderation. ${ }^{39}$ Therefore, any efforts to keep it must be taken.

Considering that ustaz in pesantren plays a big role in forming santri's understanding and practice, it is mandatory to embrace them. It is at their hands that pesantren society's obedience is formed and, more extensively, their surrounding society's obedience. ${ }^{40}$ They can be asked to spread about wasatiyyah Islam. Finally, for improvement of this study, further research is needed related to the historicity of hadiths showing that the Prophet allowed the Christian priest to do prayer at the Mosque Nabawi. Meanwhile, no ulema of hadith accept the authenticity of this hadith, while the matan of this hadith will lead to forming an extraordinary exemplary pattern of the Prophet in respecting others' beliefs.

\footnotetext{
${ }^{39}$ Masdar Hilmy, "Whither Indonesia's Islamic Moderatism? A Reexamination on the Moderate Vision of Muhammadiyah and NU," Journal of Indonesian Islam, Volume 07, Number 01 (2013), 24-48.

${ }^{40} \mathrm{~S}$. Suprapto, "Religious Leaders And Peace Building: The Role of Tuan Guru and Pedanda in Conflict Resolution in Lombok - Indonesia," Al-Jami'ah: Journal of Islamic Studies 53, no. 1 (2015), 225-250.
} 


\section{Bibliography}

Ali, Muhamad, "Kajian Naskah dan Kajian Living Qur'ān dan Living Hadith", Journal of Qur'an and Hadith Studies, Volume 4, Number 2, (2015): 147-167.

Asrohah, Hanun, "The Dynamics Of Pesantren: Responses toward Modernity and Mechanism in Organizing Transformation", Journal of Indonesian Islam, Volume 5, Number 1 (2011): 66-90.

Badan Litbang dan Diklat Kementerian Agama RI. Moderasi Beragama. Jakarta: Kementerian Agama RI, 2019.

Baidowi, Ahmad, Ahmad Salehudin, Abdul Mustaqim, Saifudin Z. Qudsi, and Nurul Hak. "Theology of Health of Quranic Pesantren in the Time of COVID-19”, HTS Teologiese Studies/Theological Studies, Volume 77, Number 4 (2021): 2-11.

Baihaqi, Ahmad bin al-Husain. Dalā'il al-Nubuwwah. 1st ed. Vol. 5. Beirut: Dar al-Kutub al-Ilmiyah, $1408 \mathrm{H}$.

Bukhari, Muhammad bin Isma'il. AlJāmi' Al-Saḩih. Beirut: Dar Ibn Katsir, 1987. Chasbullah, Arif, "Deradikalisasi terhadap Penafsiran Ayat-Ayat Qitāl", Fikri, Volume 2, Number 2 (2017): 407-424.

Gazali, Hatim, and Abd. Malik. "Pesantren and the Freedom of Thinking: Study of Ma'had Aly Pesantren Sukorejo Situbondo, East Java, Indonesia", AlJami'ah: Journal of Islamic Studies, Volume 47, Number 2 (2009): 295-316.

Gulayini, Mustofa bin Muhammad Salim. Jāmi' al-Durūs al-Arabiyyah. XXVIII. Beirut: Maktabah al'Asriyah, 1414H.

Hakim, Nurul. "Peran Pondok Pesantren dalam Membina Toleransi Kerukunan Antar Umat Beragama: Studi Kasus Pondok Pesantren Salafiyah Az-Zuhri Kota Semarang", Graduation paper, UIN Walisongo, 2015.

Hassan, Ahmad Husni, "An Islamic Perspective of the Interfaith Dialogue amidst Current Inter-Religious Tensions Worldwide”, Global Journal Al-Thaqafah, Volume 1, Number 1 (2011): 25-35.

Hilmy, Masdar. "Whither Indonesia's Islamic Moderatism? A Reexamination on the Moderate Vision of Muhammadiyah and NU", Journal of Indonesian Islam, Volume 07, Number 01 (2013): 24-48.

Ibnu Battal, 'Ali bin Khalaf. Sharh Sahih Al-Bukhari. II. Vol. 3. Riyad: Maktabah al-Rusyd, $1423 \mathrm{H}$.

Ibrahim bin Muhammad. Al-Bayān wa al-Ta'rif Fi Asbāb Wurūd al-Hadith al-Shariff. Vol. 1. Beirut: Dar al-Kutub al-'Arabiy, n.d.

Kamali, Mohammad Hashim. The Middle Path of Moderation in Islam: The Quranic Principle of Wasatiyyah. New York: Oxford University Press, 2015. 
IJIMS: Indonesian Journal of Islam and Muslim Societies, Volume 11, Number 2, December 2021: 377-401

Lajnah Pentashihan Mushaf Al-Qur'an. Moderasi Islam (Tafsir Tematik). Jakarta: Kementerian Agama RI, 2012.

Lasyin, Musa Syahin. Fath al-Mun'im Syarah Sahịh Muslim. I. Dar al-Syuruq, 1423H. Lukens-Bull, Ronald, "The Traditions of Pluralism, Accommodation, and Anti-Radicalism in the Pesantren Community", Journal of Indonesian Islam, Volume 2, Number 1 (2008): 1-15.

Metcalf, Barbara D., "Living Hadith in the Tablighỉ Jamäa'at", The Journal of Asian Studies, Volume 52, Number 3 (1993): 584-608.

Mohd Nor, Mohd Roslan, Issa Khan, and Mohammad Elius, "Analysing the Conceptual Framework of Religious Freedom and Interreligious Relationship in Islam", Indonesian Journal of Islam and Muslim Societies, Volume 8, Number 2 (2018): 309-334.

Muhammad Amin bin Abdillah. Al-Kaukāb al-Wahhāb Sharh Sahịh Muslim. I. Vol. 22. Nejd: Dar al-Minhaj, $1430 \mathrm{H}$.

Muslim bin Hajjaj. Șahih Muslim. Beirut: Dar Ihya al-Turath al-Arobiy, n.d. Mustaqim, Abdul. Tafsir Maqasidi. Indonesia: Dar al-Fikr, 2020.

Ni'am, Syamsun, "Pesantren: The Miniature of Moderate Islam in Indonesia", Indonesian Journal of Islam and Muslim Societies, Volume 5, Number 1 (2015): 111-134.

Noorhidayati, Salamah, "Relasi Antar Umat Beragama Dalam Perpektif Hadits", KALAM, Volume 10, Number 2 (2016): 501-514.

Nuryansah, Mohamad, "Aplikasi Hermeneutika Nashr Hamid Abu Zaid terhadap Hadits

Nabi”, Journal of Islamic Studies and Humanities, Volume 1, Number 2 (2016): 259-276.

Prasojo, Zaenuddin Hudi, Elmansyah Elmansyah, and Muhammed Sahrin Haji Masri. "Moderate Islam and the Social Construction of Multi-Ethnic Communities", Indonesian Journal of Islam and Muslim Societies, Volume 9, Number 2 (2019): 217-237.

Qadi, 'Iyyad. Ikmāl al-Mu'allim bi Fawà'id Muslim. I. Vol. 1. Mesir: Dar al-Wafa', $1419 \mathrm{H}$.

Qadi, 'Iyyad. Ikmāl al-Mu'allim bi Fawā'id Muslim. I. Vol. 7. Mesir: Dar al-Wafa', $1419 \mathrm{H}$.

Sayadi, Wajidi, Elmansyah, Zaenuddin Hudi Prasojo, and Ahmad Muaffaq, "Theology of Jihāad Based on the Hadith: Sahịih Bukhāri's Perspective", HTS Teologiese Studies/Theological Studies, Volume 76, Number 4 (2020): 1-8. Sumbulah, Umi, "Islam dan Ahl Al-Kitab", Al-Tahrir: Jurnal Pemikiran Islam, 
Volume 11, Number 1 (2011): 151-171.

Suprapto, S., "Religious Leaders and Peace Building: The Role of Tuan Guru and Pedanda in Conflict Resolution in Lombok-Indonesia", Al-Jami'ah: Journal of Islamic Studies, Volume 53, Number 1 (2015): 225-250.

Suyuti, 'Abdurrahman bin Abi Bakr. Al-Luma' Fi Asbāb Wurūd al-Hadith. I. Dar al-Fikr, $1416 \mathrm{H}$.

Syafi' i, Muhammad bin Idris. Ikhtiläf al-Ḥadith. II. Beirut: Dar al-Kutub al-Ilmiyah, $1429 \mathrm{H}$.

Thayyib, Ahmad. Jihad Melawan Teror. Jakarta: Pusat Studi Al-Qur'an, 2016.

Zainuddin, M., and Muhammad In'am Esha. Islam Moderat: Konsepsi, Interpretasi, Dan Aksi. Malang: UIN Maliki Press, 2016.

Zia-ul-haq, Muhammad, "Religious Diversity: An Islamic Perspectiv", Islamic Studies, Volume 49, Number 4 (2010): 493-519. 
